\title{
Immobilization of Aspergillus Oryzae $\beta$-galactosidase on Porous Magnetic Poly (GMA-DVB) Particles via Suspension Polymerization
}

\author{
Sufang Sun ${ }^{1}$, Lulu Peng ${ }^{1} \&$ Xuejie Ming ${ }^{1}$ \\ ${ }^{1}$ College of Chemistry and Environmental Science, Hebei University, Baoding, China \\ Correspondence: Sufang Sun, College of Chemistry and Environmental Science, Hebei University, Baoding, \\ China. Tel: 86-139-3139-5699. E-mail: sunsufang@hbu.edu.cn
}

Received: June 19, 2013 Accepted: July 21, 2013 Online Published: September 16, 2013

doi:10.5539/ijc.v5n4p38 URL: http://dx.doi.org/10.5539/ijc.v5n4p38

\begin{abstract}
The porous ferric GMA-DVB polymer was synthesized from glycidlymethacrylate (GMA) and divinyl benzene (DVB) by suspension polymerization with lauryl alcohol and cyclohexanol as pore-forming reagents in the presence of $\mathrm{FeCl}_{3}$ and $\mathrm{FeCl}_{2}$. The structure and the magnetism of the GMA-DVB polymer beads were featured with magnetic scales, X-ray spectroscopy and scanning electron microscope (SEM). Aspergillus Oryzae $\beta$-galactosidase was bounded on the magnetic polymer under the best terms, and the maximum activity was determined to be $271.25 \mathrm{U} / \mathrm{g}$ dry carries. Meanwhile, the fundamental properties about the bounded enzyme, such as the influence of temperature and $\mathrm{pH}$, were assayed and the satisfactory results were got.
\end{abstract}

Keywords: Aspergillus oryzae $\beta$-galactosidase, immobilization, magnetic beads, GMA-DVB ploymer, suspension polymerization

\section{Introduction}

With the growing demand for a high stereo- and chemo-specificity (Su, Zhuang, \& He, 2011) in the chemical industries such as the health care products, the agrochemicals and the pharmaceuticals, the enzyme biocatalysts are increased used (Wen \& $\mathrm{Li}, 2006$ ). Yet, for free enzyme, it is often short of long-term stability and difficult to be separated and recycled from the reaction system under the processing conditions. Hence the immobilization of the enzyme (Ma et al., 2010) received increased attention in the field of biotechnology (Pan et al., 2011) because it can provide many virtues over their free forms (Chen, 2006).

The enzymes have been immobilized on many kinds of support materials (Cao \& Li, 1999), among them, the magnetic particles, which can be easily separated from the reaction system by applying a magnetic field, have aroused strong interests to manufacture enzyme-processed products in industry (Dekker, 1990; Kronick \& Gilpin, 1986; Gupta, Hung, Lam, \& Perrier, 1988; Mehta, Upadhyay, Charles, \& Ramchand, 1997).

In our paper, the porous magnetic poly (GMA-DVB) beads with lauryl alcohol and cyclohexanol as porogenic agents were synthesized via suspension polymerization. The carriers obtained were characterized by magnetic scales, X-ray spectroscopy and scanning SEM, and then it was used to immobilize Aspergillus oryzae $\beta$-galactosidase. The major properties of the bounded enzyme, such as the enzyme activity, the thermostability, $\mathrm{pH}$ stability et al., were decided and matched up to those of the free ones.

\section{Experimental}

\subsection{Reagents and Apparatus}

O-nitrophenyl- $\beta$-D-galactoside (ONPG) and Aspergillus oryzae $\beta$-galactosidase were Sigma products. Divinyl benzene (DVB) (45\%) used as the cross-linking agent was purchased from Tianjin Kemiou Chemical Reaqent Research Institute. Azodiisobutyronitrile (AIBN) was acquired from Tianjin Fuchen Chemical Reagent Factory. The grades of other chemical reagents were analytical. All the aqueous solutions used in our experiments were made up by twice-distilled water.

DZ-6020 Vacuum Desiccator, Ultraviolet T6 New Century Spectrotometer, SHA-B Water Constant Temperature Oscillator, SHZ-D(III) Vacuum Pump with Circulated Water System and PHS-3C Digital pH Meter were applied in our research. 


\subsection{Substrate and Enzyme Solution}

$0.0150 \mathrm{~g}$ substrate was resolved in double-distilled water $(10 \mathrm{~mL})$ and the substrate solution was got. $0.0400 \mathrm{~g}$ Aspergillus oryzae $\beta$-galactosidase was resolved in the solution of $10 \mathrm{~mL}$ citric acid buffer $(0.1 \mathrm{M}, \mathrm{pH} 4.0)$ and the enzyme solution was obtained. Both the solutions acquired above were placed in the fridge for the next use.

\subsection{Synthesis of Magnetic Polymer (GMA-DVB) Bead Carriers}

The magnetic GMA-DVB polymer particles were synthesized in two successive procedures.

The magnetic GMA-DVB polymer particles were firstly synthesized by suspension polymerization. The reaction mixture, which included GMA (4 mL), divinyl benzene (DVB) $(2.3 \mathrm{~mL})$ as cross-linker, cyclohexanol $(2 \mathrm{~mL})$ and lauryl alcohol $(1.5 \mathrm{~mL})$ as porogen and initiator azodiisobutyronitrile (AIBN) $(0.0395 \mathrm{~g})$, was put into a water bath oscillator $\left(40{ }^{\circ} \mathrm{C}\right)$ to prepolymerize for some time, then the prepolymer was added into a four-necked flask containing the aqueous dispersion medium of $55 \mathrm{~mL}$ PVA $(3 \%)$ and $55 \mathrm{~mL}$ glutin $(0.2 \%)$ with $2.26 \mathrm{~g} \mathrm{FeCl}_{3}$ in it $\left(55^{\circ} \mathrm{C}\right)$, The reaction was continued at $65^{\circ} \mathrm{C}$ for $3 \mathrm{~h}$ and $2 \mathrm{~h}$ at $85^{\circ} \mathrm{C}$. The polymer beads obtained were separated and washed completely with ethanol and distilled water, and then it was immersed in ethanol to eliminate the pore-forming reagents and dried in a vacuum oven.

Secondly, the ferric poly (GMA-DVB) particles were carried on by usual co-precipitation reaction. $3.0 \mathrm{~g} \mathrm{FeCl}_{2}$ was weighed and dissolved in $120 \mathrm{~mL}$ double-distilled water, and the solution obtained was moved to a four-mouth flask, which contained 6.0g poly (GMA-DVB) beads in $25 \mathrm{~mL}$ aqueous ammonia. The reaction was done at three different sequential temperatures for the same time $(2 \mathrm{~h})$ under nitrogen protection, i.e. $40^{\circ} \mathrm{C}$ for $2 \mathrm{~h}$, $50{ }^{\circ} \mathrm{C}$ for $2 \mathrm{~h}$ and $90^{\circ} \mathrm{C}$ for $2 \mathrm{~h}$, the magnetic poly (GMA-DVB) beads obtained were poured out from the reactor, soaked in absolute alcohol for $3 \mathrm{~h}$ to separate liquid porogenic agent and washed with distilled water completely, then it were moved to phosphate buffer ( $\mathrm{pH} 8.0,27 \mathrm{~mL}$ ) having $3 \mathrm{~mL} \mathrm{50 \%} \mathrm{glutaraldehyde.} \mathrm{The} \mathrm{reaction} \mathrm{was}$ stirred for $6 \mathrm{~h}$ at $25^{\circ} \mathrm{C}$, and the products acquired were successively washed with $0.1 \mathrm{M}$ acetic acid solution and distilled water, after being dried in a vacuum oven. The magnetic microspheres was obtained and stored to be used in the next step.

\subsection{Aspergillus Oryzae $\beta$-galactosidase Immobilization}

$0.0500 \mathrm{~g}$ carriers was put into $0.5 \mathrm{~mL}$ the enzyme solution and the reaction was carried out at $25^{\circ} \mathrm{C}$ for $3 \mathrm{~h}$, after that, the bounded enzymes were separated and washed thoroughly with distilled water to remove the unimmobilized $\beta$-galactosidase.

\subsection{Activity Assays of Both Kinds of $\beta$-galactosidase}

Activities of both $\beta$-galactosidase were determined according to the references (Zhang, S. Gao, \& G. Gao, 2010; Bayramoglu, Tunali, \& Arica, 2007), using ONPG $(1.5 \mathrm{mg} / \mathrm{mL})$ as substrate. For the activity of free enzyme, 0.1 $\mathrm{mL}$ of it was put into a tube containing $0.9 \mathrm{~mL} 0.1 \mathrm{M}$ citric acid buffer $(\mathrm{pH} 5.0)$, then $0.2 \mathrm{~mL} 1.5 \mathrm{mg} / \mathrm{mL} \mathrm{ONPG}$ was added into it, the reaction began, after exactly $15 \mathrm{~min}$ at $55^{\circ} \mathrm{C}$, the reaction was ceased by the addition of 2.0 $\mathrm{mL} 1 \mathrm{M} \mathrm{Na}_{2} \mathrm{CO}_{3}$ solution and the ONP produced was determined exactly at $420 \mathrm{~nm}$. For the activity of the bounded one, $0.0500 \mathrm{~g}$ of it was weighted and immersed in $1.0 \mathrm{~mL}$ buffer solution used above. The reaction was done and analyzed as described above. The activity yield was counted as the ratio of activity of the bound enzyme to that of all free enzyme activity used in the process of the immobilization. Under the experiment conditions, one unit of enzyme activity was defined as the quantity of the enzyme producing $1 \mu$ mol of ONP per minute.

\subsection{Influence of Temperature and $p H$}

The influence of temperature on the activities of both kinds of enzymes was assayed from $40{ }^{\circ} \mathrm{C}$ to $65{ }^{\circ} \mathrm{C}$. Thermal stabilities of both kinds of $\beta$-galactosidase were analyzed at $55^{\circ} \mathrm{C}$ after a long time exposed to different temperature $\left(50^{\circ} \mathrm{C}\right.$ and $\left.60^{\circ} \mathrm{C}\right)$.

The pH-activity over the scope of 3.0-10.0 was assayed for both kinds of enzymes including the free and the bound one at $55^{\circ} \mathrm{C}$ with ONPG as substrate, and the stability of $\mathrm{pH}$ ranging from 2.0 to 9.0 was tested at $55^{\circ} \mathrm{C}$ after they were exposed various $\mathrm{pH}$ for $30 \mathrm{~min}$.

\subsection{Operational Stability}

According to the following process, the operational stability of the immobilized enzyme was assayed. $0.0500 \mathrm{~g}$ immobilized enzyme was weighed and immersed in $1 \mathrm{~mL} 0.1 \mathrm{M}$ sodium phosphate buffer over a period of 30min, then, the activity of the enzyme was determined according to the assays of $\beta$-galactosidase activity. Afterward, the carrier was filtered and washed with distilled water and under the same conditons, the experiment above was repeated 7 times. 


\section{Results and Discussion}

\subsection{Discussion about the Magnetic Porous Poly (GMA-DVB) Beads}

The magnetic poly (GMA-DVB) beads were evidenced by magnetic scales and X-ray spectroscopy. The magnetic scales showed that the quality of the sample was $24.7651 \mathrm{~g}$ when the current was 1.5 A without a magnetic field and it was $25.1541 \mathrm{~g}$ when the magnetic field intensity was $150.0 \mathrm{mT}$. It's easy to find that the quality of the sample was increasing with a magnetic field, which illustrated that the beads obtained had magnetic property. Meanwhile, the X-ray spectroscopy for the poly (GMA-DVB) prepared was also obtained and the result was listed in Figure 1. It clearly showed that the beads described above contained Fe. Both the results above indicated that magnetism was successfully formed within the structure of poly (GMA-DVB) particles.

Full scale counts: 1296

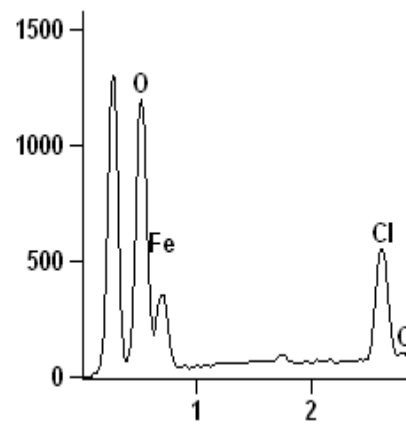

klm - 1 - H hbu (18)

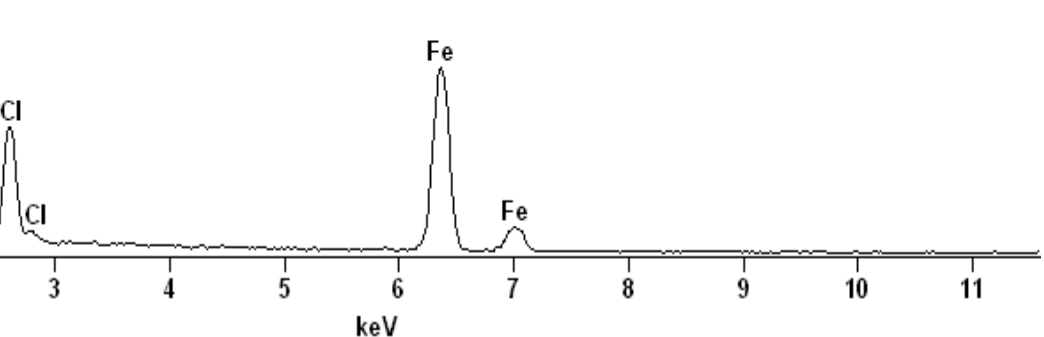

Figure 1. An energy dispersive X-ray spectrum of ferric poly(GMA-DVB) particles

Meanwhile, the surface structure of carriers obtained was characterized by the micrographs of scanning electron microscopy (SEM), and the results were illustrated in Figure 2. The photographs showed that the magnetic poly(GMA-DVB) beads had a porous surface structure, which would be more fit for the immobilization of enzymes because of the increase of the surface area.

Under the optimum conditions, the poly(GMA-DVB) beads with magnetic property were used to bound Aspergillus oryzae $\beta$-galactosidase, and the results indicated that the maximum value of the enzyme activity was $271.25 \mathrm{U} / \mathrm{g}$ dry supporter and the activity recovery of the immobilized $\beta$-galactosidase was $40.36 \%$.
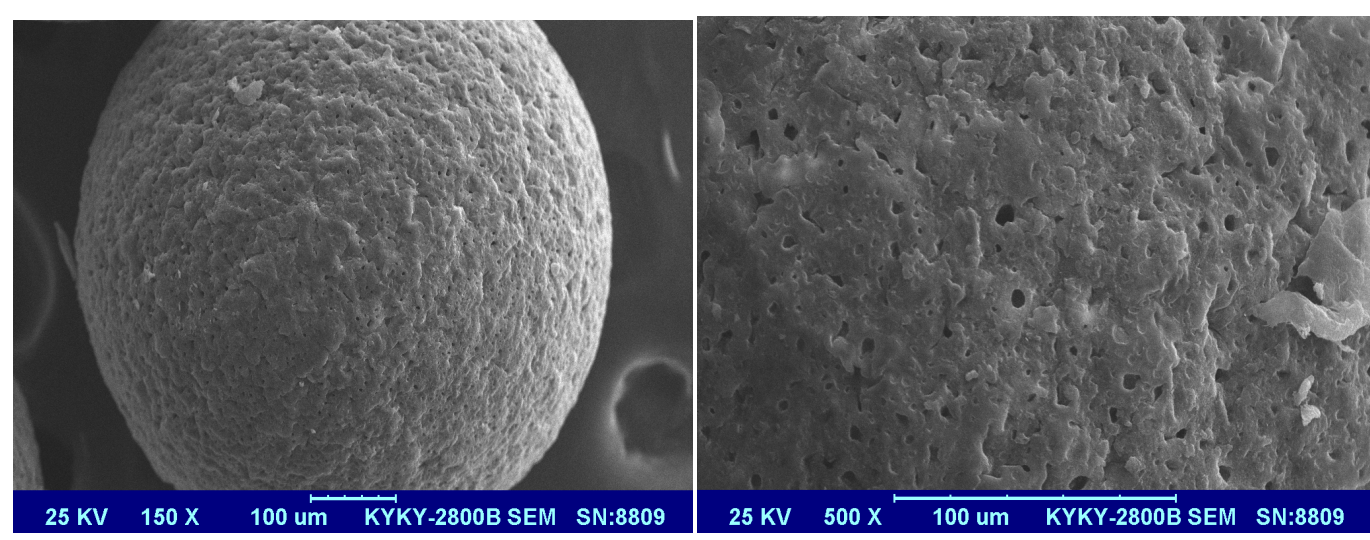

Figure 2. SEM photographs of the ferric GMA-DVB polymer particles 


\subsection{Properties of Both Kinds of $\beta$-galactosidase}

\subsubsection{Temperature Optima and Thermostability}

The enzyme activities were assayed at different temperature $\left(40-65^{\circ} \mathrm{C}\right)$ for $15 \mathrm{~min}$ at $\mathrm{pH} 5.0$, and the results showed that the optimum temperature of both kinds of enzyme was $55^{\circ} \mathrm{C}$.

The thermostability of the free and bounded enzyme were obtained in $50{ }^{\circ} \mathrm{C}$ and $60^{\circ} \mathrm{C}$ and the results showed that the residual activity was $60.6 \%$ for the bounded enzyme and $50.9 \%$ for the free one at $50{ }^{\circ} \mathrm{C}$ for $8 \mathrm{~h}$, and the remaining activity was $58.1 \%$ for the former and $48.2 \%$ for the later at $60{ }^{\circ} \mathrm{C}$ over the same time. Results indicated that the thermal stability of the immobilized enzyme was better than the free one.

\subsubsection{PH Optima and Stability}

The enzyme activities were tested at $55^{\circ} \mathrm{C}$ for $15 \mathrm{~min}$ in various $\mathrm{pH}$ ranging from 3.0 to 10.0 , and the results indicated that the optimum activities of both the free enzyme and the immobilized one were 5.0.

The effect of $\mathrm{pH}$ on both kinds of enzyme activities was discussed by changing $\mathrm{pH}$ of the phosphate buffer. It could be shown in the experiments that the $\mathrm{pH}$ stability range was 5.0-8.0 for the free enzyme and it was 3.0-8.0 for the immobilized enzyme. Results obtained above indicated that acid-proof property of the immobilized enzyme increased greatly because it had a wider $\mathrm{pH}$ range than the free enzyme.

\subsubsection{Operational Stability of $\beta$-galactosidase}

Using method described above, the tests were duplicated 7 times with the identical ONPG concentration and the bounded enzyme, the results obtained saw Table 1, it illustrated that the immobilized enzyme had not significant loss in activity after being used 7 times, implying the enzyme was hardly separated from the magnetic polymer particles during reaction, the results described above showed that the bounded enzyme had a good operational stability.

Table 1. Operational stability

\begin{tabular}{cccccccc}
\hline Times & 1 & 2 & 3 & 4 & 5 & 6 & 7 \\
\hline Relative absorbance (\%) & 100 & 99.7 & 98.9 & 98.6 & 99.1 & 97.9 & 98.2 \\
\hline
\end{tabular}

\section{Conclusion}

The porous magnetic poly (GMA-DVB) beads were prepared from glycidyl methacrylate (GMA) and divinyl benzene (DVB), with cyclohexanol and lauryl alcohol as porogenic agent and azodiisobutyronitrile (AIBN) as initiator under $\mathrm{FeCl}_{3}$ and $\mathrm{FeCl}_{2}$ solution via suspension polymerization. The results obtained from magnetic scales and X-ray spectroscopy showed that magnetism was successfully formed within the poly (GMA-DVB) beads, and the SEM micrographs showed that the magnetic beads have a porous surface structure. Aspergillus oryzae $\beta$-galactosidase was bounded on the magnetic beads obtained under the optimum conditions. The activity of the immobilized enzyme and the properties of it were determined and the results were in comparison with that of the free enzyme, satisfactory results were got in the properties of the immobilized enzyme, such as the thermostability, $\mathrm{pH}$ stability and the operational stability. In addition, the magnetic beads as enzyme immobilization carrier were easily separated from substrate solution under the external electric field, which was convenient for recycling use of the immobilized enzyme and saved the cost greatly. Considering the facts described above, the magnetic poly (GMA-DVB) prepared here as enzyme immobilization carrier had great potentialities for industrial use and it was very valuable to be studied further.

\section{Acknowledgements}

This work was supported by funds from the Natural Science Foundation of Hebei Province.

\section{References}

Bayramoglu, G., Tunali, Y., \& Arica, M. Y. (2007). Immobilization of $\beta$-galactosidase onto magnetic poly (GMA-MMA) beads for hydrolysis of lactose in bed reactor. Catalysis Communications, 8(7), 1094-1101. http://dx.doi.org/10.1016/j.catcom.2006.10.029

Cao, S. X., \& Li, W. (1999). The research progress of immobilized enzyme preparation. Environmental Protection of Chemical Industry, 19(5), 273-277 
Chen, J. L., \& Qi, J. C. (2006). The research progress of immobilized enzyme. Chemical and Biological Engineering, 23, 7-9.

Dekker, R. F. H. (1990). Application of a magnetic immobilized $\beta$-glucosidase in the enzymatic saccharification of steam-exploded lignocellulosic residues. Applied Biochemistry and Biotechnology, 23(1), 25-39. http://dx.doi.org/10.1007/BF02942050

Gupta, P. K., Hung, C. T., Lam, F. C., \& Perrier, D. G. (1988). Albumin microspheres. III. Synthesis and characterization of microspheres containing adriamycin and magnetite. International Journal of Pharmaceutics, 43(1-2), 167-177. http://dx.doi.org/10.1016/0378-5173(88)90072-5

Kronick, P., \& Gilpin, R. W. (1986). Use of superparamagnetic particles for isolation of cells. Journal of Biochemical and Biophysical Methods, 12(1-2), 73-80. http://dx.doi.org/10.1016/0165-022X(86)90052-7

Ma, Y. F., Lv, S. H., Liu, G., Dong, L. X., Li, F., Wang, F., \& Zheng, X. J. (2010). Research Progress of the Enzymatic Polymerization. Biotechnology Bulletin, 4, 50-54.

Mehta, R. V., Upadhyay, R. V., Charles, S. W., \& Ramchand, C. N. (1997). Direct binding of protein to magnetic particles. Biotechnology Techniques, 11(7), 493-496. http://dx.doi.org/10.1023/A:1018457915380

Pan, Z. Y., Hua, L., Qiao, Y. X., Yang, H. M., Zhao, X. G., Feng, B., . . Hou, Z. S. (2011). Nanostructured Maghemite-Supported Silver Catalysts for Styrene Epoxidation. Chinese Journal of Catalysis, 32(3-4), 428-435. http://dx.doi.org/10.1016/S1872-2067(10)60183-0

Su, L., Zhuang, Y., \& He, B. F. (2011). Recent advances in directed evolution of enzyme and its application in industrial biocatalysis. Chinese Journal of Bioprocess Engineering, 9(4), 69-75.

Wen, Y. X., \& Li, J. K. (2006). The detection of organophosphorus pesticide residues by plant esterase. Food Science, 27(4), 123-126.

Zhang, S. T., Gao, S. F., \& Gao, G. Q. (2010). Immobilization of $\beta$-Galactosidase onto Magnetic Beads. Applied Biochemistry and Biotechnology, 160(5), 1386-1393. http://dx.doi.org/10.1007/s12010-009-8600-5

\section{Copyrights}

Copyright for this article is retained by the author(s), with first publication rights granted to the journal.

This is an open-access article distributed under the terms and conditions of the Creative Commons Attribution license (http://creativecommons.org/licenses/by/3.0/). 